ENTREPRENEURSHIP AND SUSTAINABILITY ISSUES

ISSN 2345-0282 (online) http://jssidoi.org/jesi/ 2020 Volume 8 Number 1 (September)

http://doi.org/10.9770/jesi.2020.8.1(45)

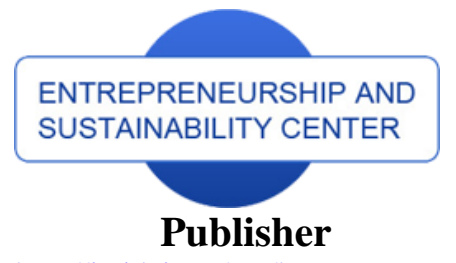

http://jssidoi.org/esc/home
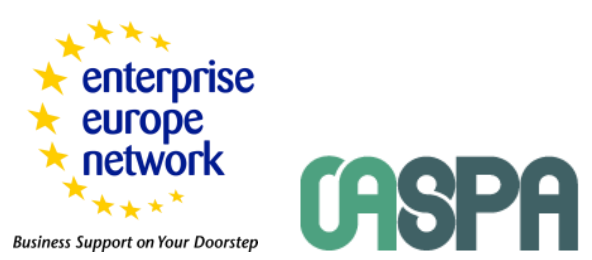

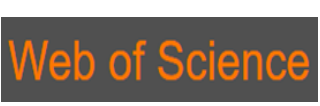

Clarivate
Analytics

\title{
DEMOGRAPHIC AND MIGRATION PROCESSES OF LABOR POTENTIAL: A CASE STUDY THE AGRICULTURAL SECTOR OF THE REPUBLIC OF KAZAKHSTAN
}

\author{
Gulmira Nurzhanova ${ }^{1}$, Galym Mussirov ${ }^{2}$, Shakizada Niyazbekova ${ }^{3}$, Akilbek Ilyas ${ }^{4}$, Yuliya Tyurina ${ }^{5}$, \\ Leila Maisigova $^{6}$, Marija Troyanskaya ${ }^{7}$, Kymbat Kunanbayeva ${ }^{8}$ \\ ${ }^{1}$ Financial Academy, 25 Esenberlin street, 010000, Nur-Sultan, Kazakhstan \\ ${ }^{2}$ Baishev University, st. Zhubanov Brothers 302A, 030000, Aktobe, Kazakhstan \\ ${ }^{3}$ Moscow Witte University, 2 Kozhuhovski proezd 12 stroenie 1, 115432, Moscow, Russia \\ ${ }^{4}$ Financial Academy, 25 Esenberlin street, 010000, Nur-Sultan, Kazakhstan \\ ${ }^{5}$ Financial University under the Government of the Russian Federation, 49, Leningradsky Prospekt, 125167, Moscow, \\ Russian Federation \\ ${ }^{6}$ Ingush State University, pr. Zyazikova, 7, 386001, Magas city, Russian Federation, \\ ${ }^{7}$ Orenburg State University, Avenue Victory, d. 13, 460018, Orenburg city, Russian Federation \\ ${ }^{8}$ Financial University under the Government of the Russian Federation, 49, Leningradsky Prospekt, 125993, Moscow,
} Russian Federation

E-mails: ${ }^{1}$ gulislam@mail.ru; ${ }^{2}$ mysirov@mail.ru $;{ }^{3}$ shakizada.niyazbekova@ gmail.com; ${ }^{4}$ akilbeki.ilias@mail.ru
${ }^{5}$ u turina@mail.ru, ${ }^{6}$ maisigova@yahoo.com, ${ }^{7}$ m trovanskava@mail.ru, ${ }^{8}$ kunanbaeva kymbat@mail.ru

Received 2 April 2020; accepted 18 June 2020; published 30 September 2020

\begin{abstract}
It is very important to study the demographic and migration processes in the country when forming the labor potential of rural areas. Using these indicators affecting the labor potential, we calculated the parameters of linear trend models, checking their adequacy of the constructed models, calculated the determination coefficients, and built confidential intervals for the forecasts. In order to present a quantitative model expressing the general tendency of the time series change over time, we used the analytical alignment of the time series. In this case, the actual levels were replaced by levels calculated on the basis of certain data. As a result, we got the result of a change in time of the studied indicators in a positive direction. Obtained results: outflow of external and internal migration is the reason for the decline of labor potential in the country, but in general does not affect the efficiency of labor potential of the village; indicators of the population in general, i.e., the population of cities and villages, internal and external migration with natural population growth are quite close to one, what means that their forecast changes are insignificant and do not undergo significant changes in the future. Finally, with a 95\% probability, we can expect that in 2020 - 2021, the indicators under consideration will not take values less than the lower limits of confidence forecast intervals and not greater than their upper limits. Obtain results are very important for development of a strategy for the effective use of labor potential.
\end{abstract}

Keywords: demography; migration; labor potential; agriculture; urban population; rural population; birth rate; labor market

Reference to this paper should be made as follows: Nurzhanova, G., Mussirov, G., Niyazbekova, Sh., Ilyas, A., Tyurina, Yu., Maisigova, L., Troyanskaya, M., Kunanbayeva K. 2020. Entrepreneurship and Sustainability Issues, 8(1), 656-671. http://doi.org/10.9770/jesi.2020.8.1(45)

JEL Classifications: E20, J01, J11, F16, O15. 


\section{Introduction}

Agriculture plays an important role in the economic and social life of any country (Baltgailis, 2019; Vigliarolo, 2020), (Issayeva, 2019). The level of agricultural development largely determines the economic security of the country.

Since the climate and geographical location of Kazakhstan is favorable for agriculture, the country has all the opportunities for the development of a competitive agricultural sector in the world market. In addition, the social situation of almost half of the country's population is in close contact with the countryside. As the village is an important factor in the economic development of the Republic, then the rural population is an important factor in the socio-political stability of the country,

We believe that demographic and migration policy is a multifaceted integrated process that develops in close contact with all socio-political, economic processes in society. Today, demography and migration is not only an economic concept, but also a socially significant concept.

For the continuous reproduction of labor resources, an important prerequisite is the demographic situation in the country. The demographic situation is a complex and integrated process that is directly related to the sociopolitical, economic development of society.

The country's transition to a market system has also created many favorable conditions for the development of migration. Migration processes effect on the labor supply of the regions, and, as a consequence, on their economic development. Structural transformations of the economy of several regions of Kazakhstan towards the preferential development of the agro-industrial complex raise the value of the reproductive process of the labor potential of a village to a new level.

Taking into account the proportion of Kazakhs living abroad, which make up almost a third of the population of Kazakhstan, the diaspora is a significant social resource of an independent state. Note that presumably more than half of ethnic migrants have agricultural education and skills, and every fourth repatriate is employed in agriculture (Bodaukhan, 2017).

Studies of the quantitative and qualitative characteristics of modern migration movements oriented to the countryside are of great interest, the influence of migrants on the labor market, which is forming in the agricultural sector, as well as the processes of adaptation of migrants in rural areas. In this regard, the study of modern migration processes, the analysis of the extent, directions and factors that determine them, as well as the identification of various aspects of the migration impact on the state of agriculture is very relevant.

The quantitative basis of labor potential, in our opinion, is not labor resources, but the population. As part of the population, labor resources characterize the demographic and migration situation in the country through qualitative and quantitative indicators. Therefore, quantitative changes in labor potential will depend on the general demographic and migration situation. 


\section{ENTREPRENEURSHIP AND SUSTAINABILITY ISSUES}

ISSN 2345-0282 (online) http://jssidoi.org/jesi/

2020 Volume 8 Number 1 (September)

http://doi.org/10.9770/jesi.2020.8.1(45)

\section{Literature review}

The demography has a set of statistical data on the composition of the population, its size, density, age and gender composition. Among the main concepts of demography, one can name such concepts: fertility, mortality, natural population migration, lifetime, life potential of the population, population migration. Examined a conceptual study of the migration impact on the economy in a more complete and complex state, taking into account not only the genesis and structure, but also the characteristics of activities in a framework of transition economy, and in his dissertation he writes: "We consider population migration as social -economic category, based on the fact that the division of labor relates primarily to the sphere of production, ownership, property" (Mukhammedov 2007).

The theoretical study of the role of international population migration in demographic development is particularly important. At the same time, we emphasize that there is no clear definition of the concept of "demographic development" both in the Kazakh and foreign scientific literature. In our opinion, development in general and demographic development in particular are multifaceted concepts that imply development with a plus sign (progress) and development with a minus sign (regression). Thus, in our understanding, demographic development is both positive and negative changes in the quantitative and qualitative characteristics of the population of a country (Iontsev, Prokhorova, 2014).

An example is a duplicitous demographic situation prevailing in Europe. On the one part, there is an increase in lifetime, infant mortality decreases - progress is obvious. On the other part, fundamental changes in the family the preference for free relations instead of traditional marriage, the conscious refusal of having children, the spread of marriages of people with a non-traditional orientation - can be considered as indicators of regression. But all this is a demographic development in all its diversity (Iontsev, Prokhorova, 2014).

If we talk about rural-urban migration, it can be assumed that a reduction in land inheritance predicts a significantly greater tendency to migrate to urban areas and find jobs in the non-agricultural sector, i.e. in the city (Holden et al., 2014).

In some scientific studies, it is indicated that intentions to stay in agriculture increase when the inherited land among young people is existing (Bezu, Holden, 2014). They do not find a connection between themselves. However, land inheritance and migration may be due to the broad definition of migration, that they are applicable. Presumably, the expected return to migration will be conditional on the likelihood of employment and the expected wage gap between origin and destination (Harris, Todaro, 1970), both are likely to be more pronounced in case of rural origin and urban direction. This motivates our use of the demographic and migration factor.

Since we consider the influence of demographic and migration processes on labor potential in the article, we consider it necessary to take into account the views of scientists on the concept of "labor potential". Kostakov V. and Popov A. believe that "the labor potential of a country and its regions is the labor resources considered from the point of view of the unity of quantitative and qualitative indicators" (Kostakov, Popov, 1982). Some authors began to include many factors characterizing the totality of socio-economic and organizational-managerial capabilities that allow working in the number of socio-economic criteria. Such a characteristic of labor potential is presented in the article by Vigliarolo (Vigliarolo, 2020). The concept of "labor potential" includes labor resources, working conditions, population and employment, the level of education, the totality of the technical infrastructure of labor, which have been used by employees of planning and statistics bodies for a long time (Fedorov, 2005).

Demography (Greek demos - population, qrapho - I write): 1) scientific discipline on the laws of population growth and its socio-historical substantiated processes; 
ISSN 2345-0282 (online) http://jssidoi.org/jesi/ 2020 Volume 8 Number 1 (September) http://doi.org/10.9770/jesi.2020.8.1(45)

2) socio - economic demography - a scientific field that studies the population, its geography, structure and composition, quantitative and spatial - periodic dynamics, birth rate, mortality, lifetime with their socio historical characteristics;

3) biological demography - a set of statistical data on the density, youth and sexual composition of the population (Dal, 2018). Further, De Brauw, A Mueller and Woldehanna wrote on the relationship between migration and land. Employment opportunities in rural areas are limited outside agriculture (De Brauw et al. 2013). Education was the strongest motivation for migrating from the countryside to the city (De Brauw, 2014).

\section{Overview of socio-demographic trends}

Today, for the Republic of Kazakhstan, the most important is the methods of forming the labor market, the methods of economic growth, the creation and implementation of employment policies through the methods of efficient use of man power using statistics data.

Labor potential is determined by the average age and gender structure of the population, lifetime, level of education and training, the reserve of man power, which is carried out under certain circumstances, etc.

As of January 1, 2019, the total number of the Republic of Kazakhstan amounted to 18395.6 thousand people. In 2019, the population was increased by 2192300 thousand people compared to 2010 or by $13.53 \%$. Of these, the urban population is 10509798 thousand. people, the rural population - 7647539 thousand people (Table 1, Figure 1).

Table 1. Dynamics of socio - demographic indicators of the Republic of Kazakhstan for 2010-2019

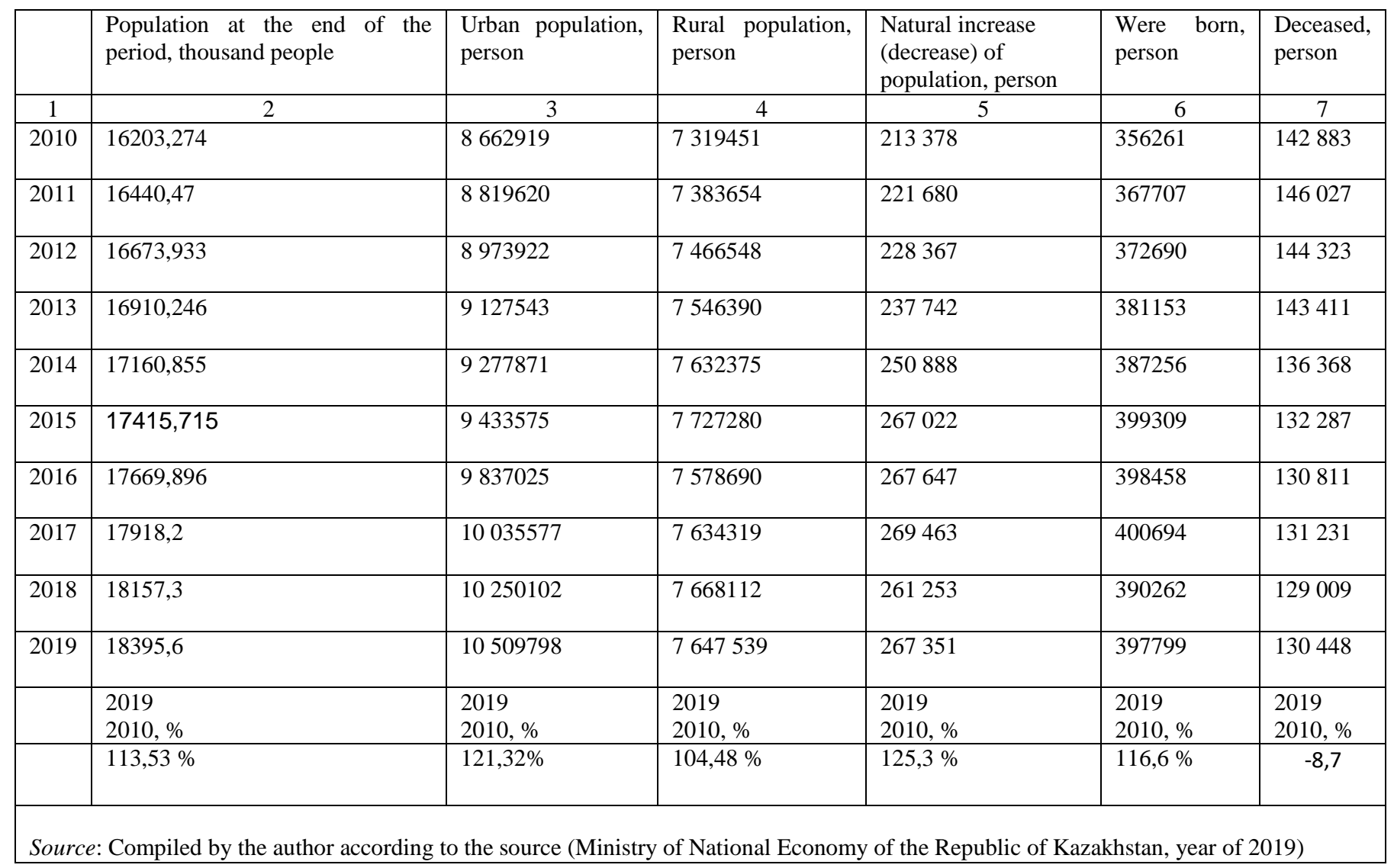




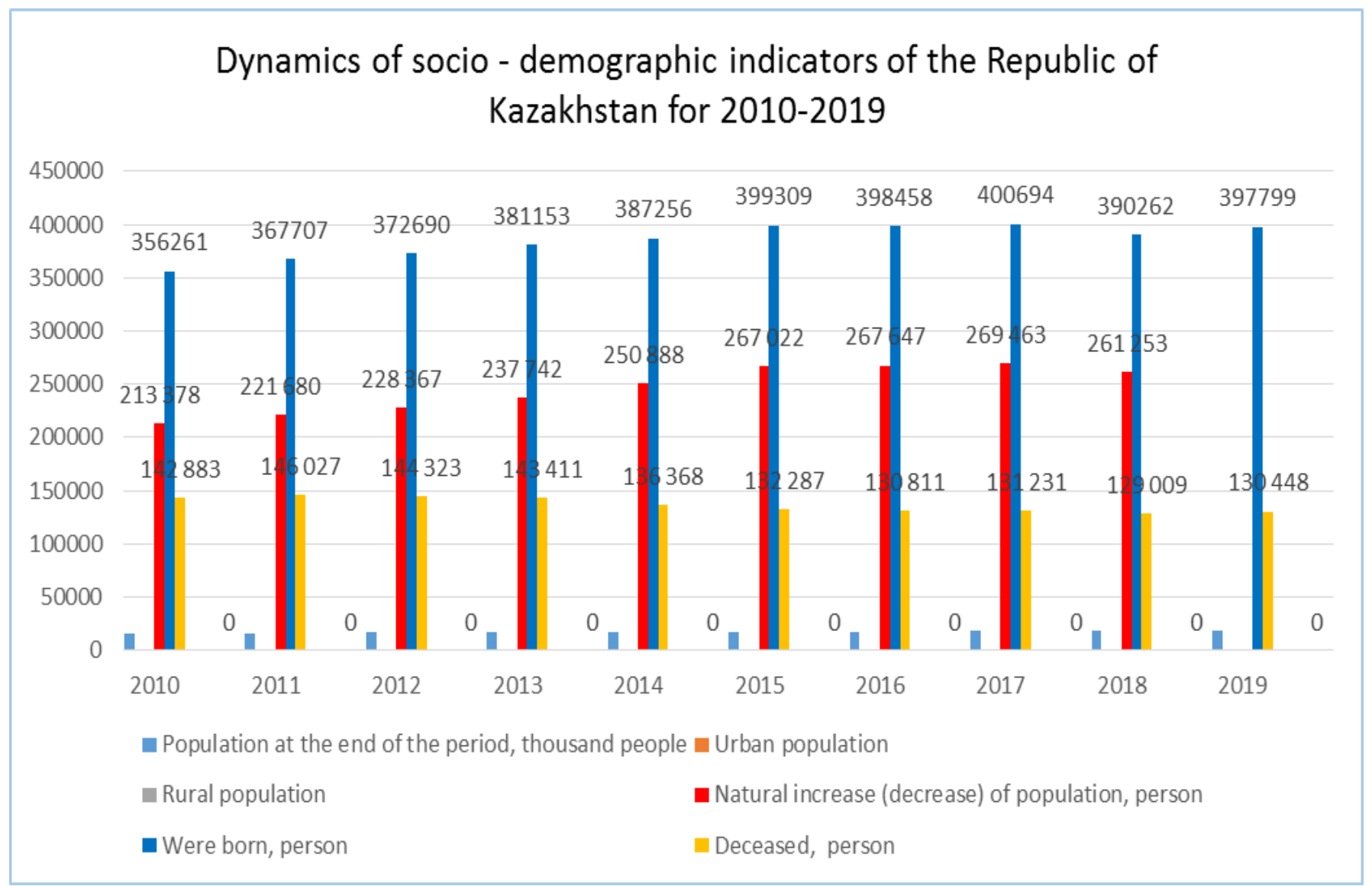

Figure 1. Dynamics of socio - demographic indicators of the Republic of Kazakhstan for 2010-2019

Compared to 2010 , the urban population grew by $1,846,879$ thousand people, or $21.32 \%$, the rural population by 328,088 thousand people, accordingly, by $4.48 \%$. We observe an increase in urban population than rural. The natural increase (decrease) in the population in 2010 was 213,378 people, in 2019, was increased up to 267,351 people, or $25.3 \%$. Meanwhile, we see a decrease in the number of deaths compared to 2010 by 12,435 people at the end of 2019, or $-8.7 \%$. This indicates a significant improvement in the socio-economic situation of the population of Kazakhstan (Ministry of National Economy of the Republic of Kazakhstan in 2019). 


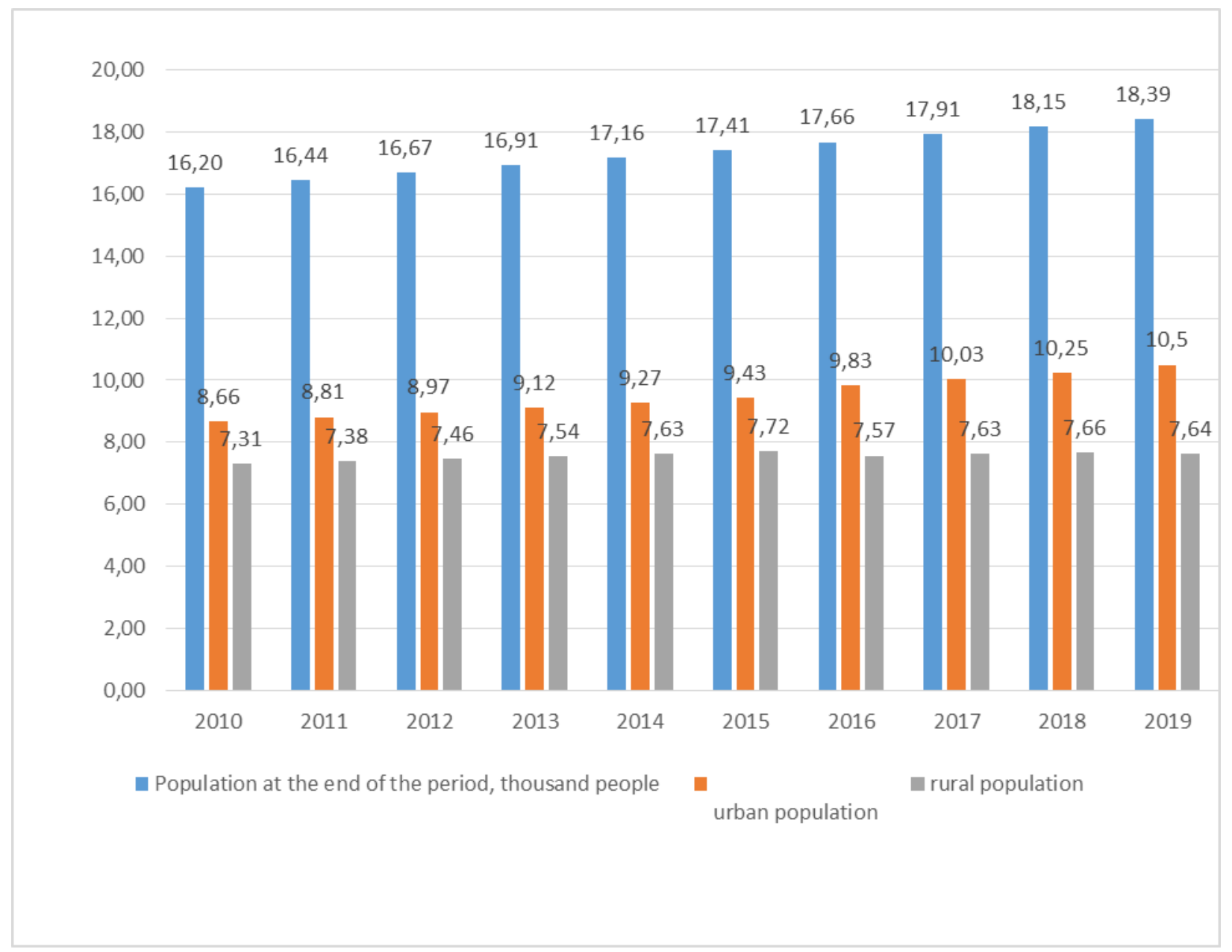

Figure 2. Dynamics of urban and rural population of the Republic of Kazakhstan for 2010 -2019

Labor migration is an important factor in achieving sustainable development of the economic sector (Semenyuk, 2019). Currently, economic and other problems occurring in the world do not reduce the number of labor migrants, but increase the number of people wishing to leave the country.

Table 2. Migration of the population of the Republic of Kazakhstan for 2010-2019, person

\begin{tabular}{|l|l|l|l|}
\hline Years & Balance of migration (+-) & Arrived, person & Departed, person \\
\hline Total & \multicolumn{3}{|l|}{} \\
\hline 2010 & 7526 & 406166 & 398640 \\
\hline 2011 & 15516 & 408094 & 392578 \\
\hline 2012 & 5069 & 402654 & 397558 \\
\hline 2013 & -1426 & 366137 & 367563 \\
\hline 2014 & -279 & 361372 & 361651 \\
\hline 2015 & -12162 & 422400 & 434562 \\
\hline 2016 & -13466 & 472032 & 485498 \\
\hline 2017 & -21145 & 630649 & 651794 \\
\hline 2018 & -22130 & 946415 & 968545 \\
\hline
\end{tabular}


ENTREPRENEURSHIP AND SUSTAINABILITY ISSUES

ISSN 2345-0282 (online) http://jssidoi.org/jesi/ 2020 Volume 8 Number 1 (September) http://doi.org/10.9770/jesi.2020.8.1(45)

\begin{tabular}{|c|c|c|c|}
\hline 2019 & -29121 & 900931 & 930052 \\
\hline \multicolumn{4}{|c|}{ External migration } \\
\hline Years & Balance of migration (+-) & Immigrant & Emigrant \\
\hline 2010 & 7526 & 41511 & 33985 \\
\hline 2011 & 15516 & 42057 & 26541 \\
\hline 2012 & 5096 & 38016 & 32920 \\
\hline 2013 & -1426 & 28296 & 29722 \\
\hline 2014 & -279 & 24105 & 24384 \\
\hline 2015 & -12162 & 16784 & 28946 \\
\hline 2016 & -13466 & 16581 & 30047 \\
\hline 2017 & -21145 & 13755 & 34900 \\
\hline 2018 & -22130 & 15595 & 37725 \\
\hline 2019 & -29121 & 12747 & 41868 \\
\hline \multicolumn{4}{|c|}{ Internal migration } \\
\hline 2010 & & 364655 & 364655 \\
\hline 2011 & & 366037 & 366037 \\
\hline 2012 & & 364638 & 364638 \\
\hline 2013 & & 337841 & 337841 \\
\hline 2014 & & 337267 & 337267 \\
\hline 2015 & & 405616 & 405616 \\
\hline 2016 & & 455451 & 455451 \\
\hline 2017 & & 616894 & 616894 \\
\hline 2018 & & 930820 & 930820 \\
\hline 2019 & 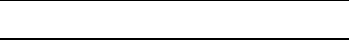 & 888184 & 888184 \\
\hline
\end{tabular}

\section{External migration}

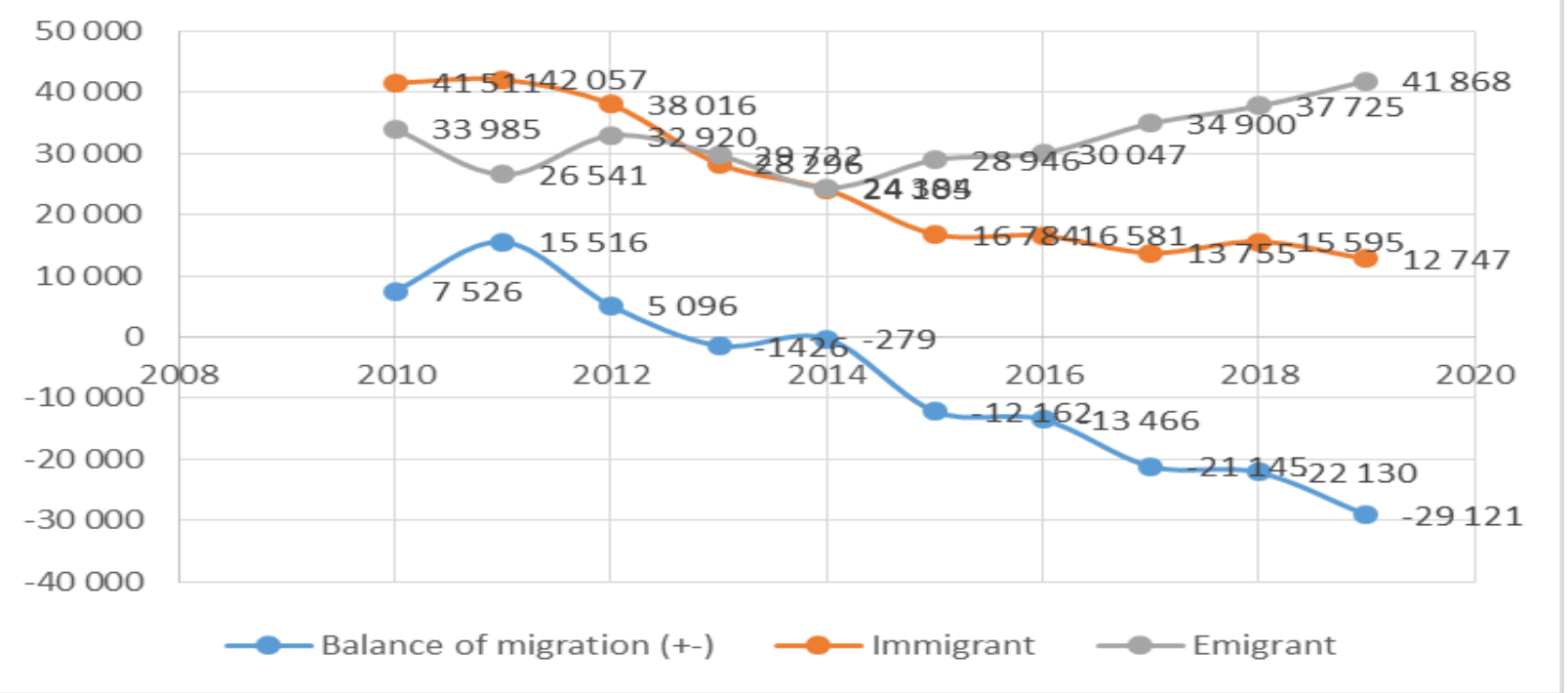

Figure 3. External migration of the Republic of Kazakhstan for 2010-2019, person 


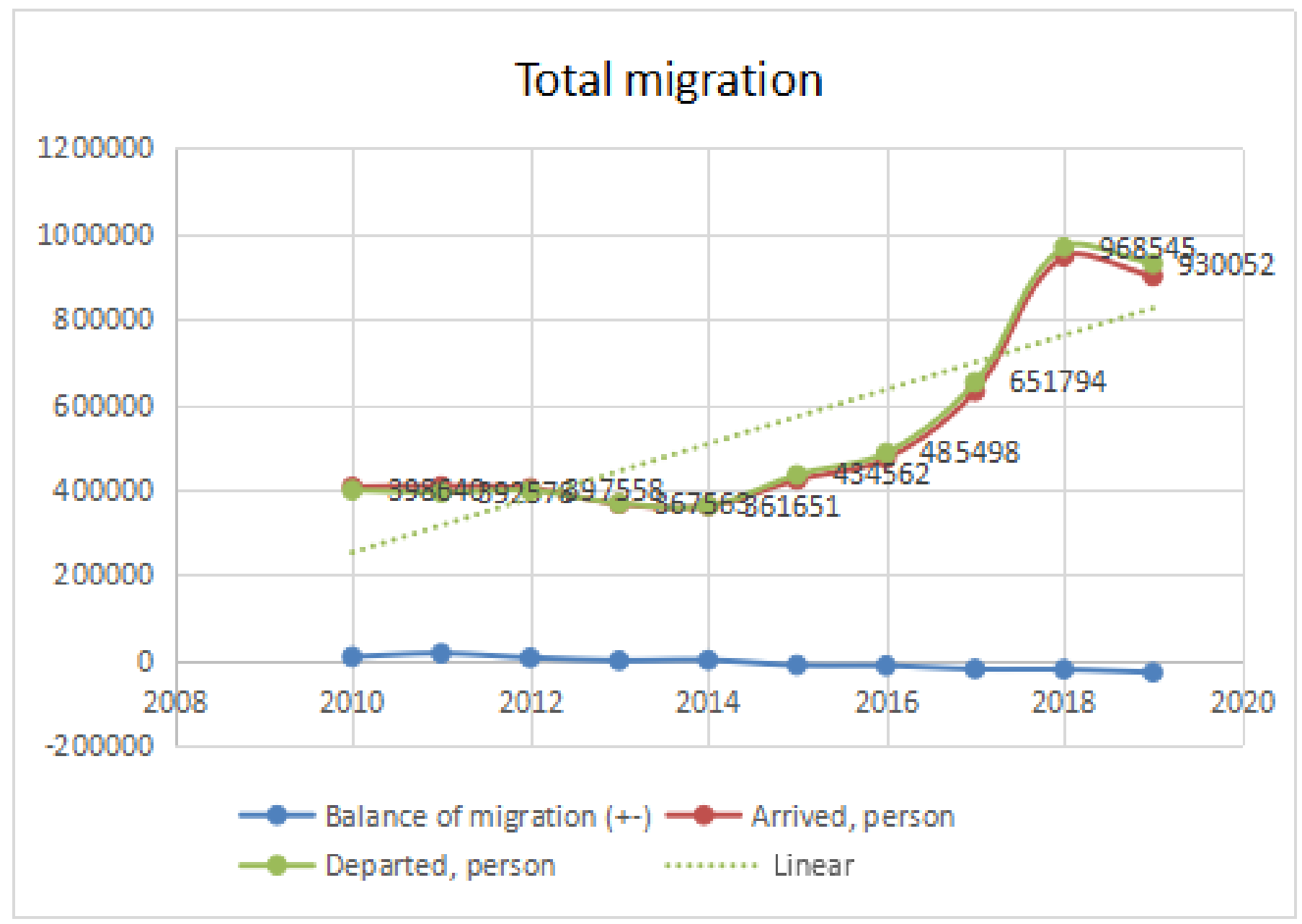

Figure 4. Total migration of the Republic of Kazakhstan for 2010-2019, person 


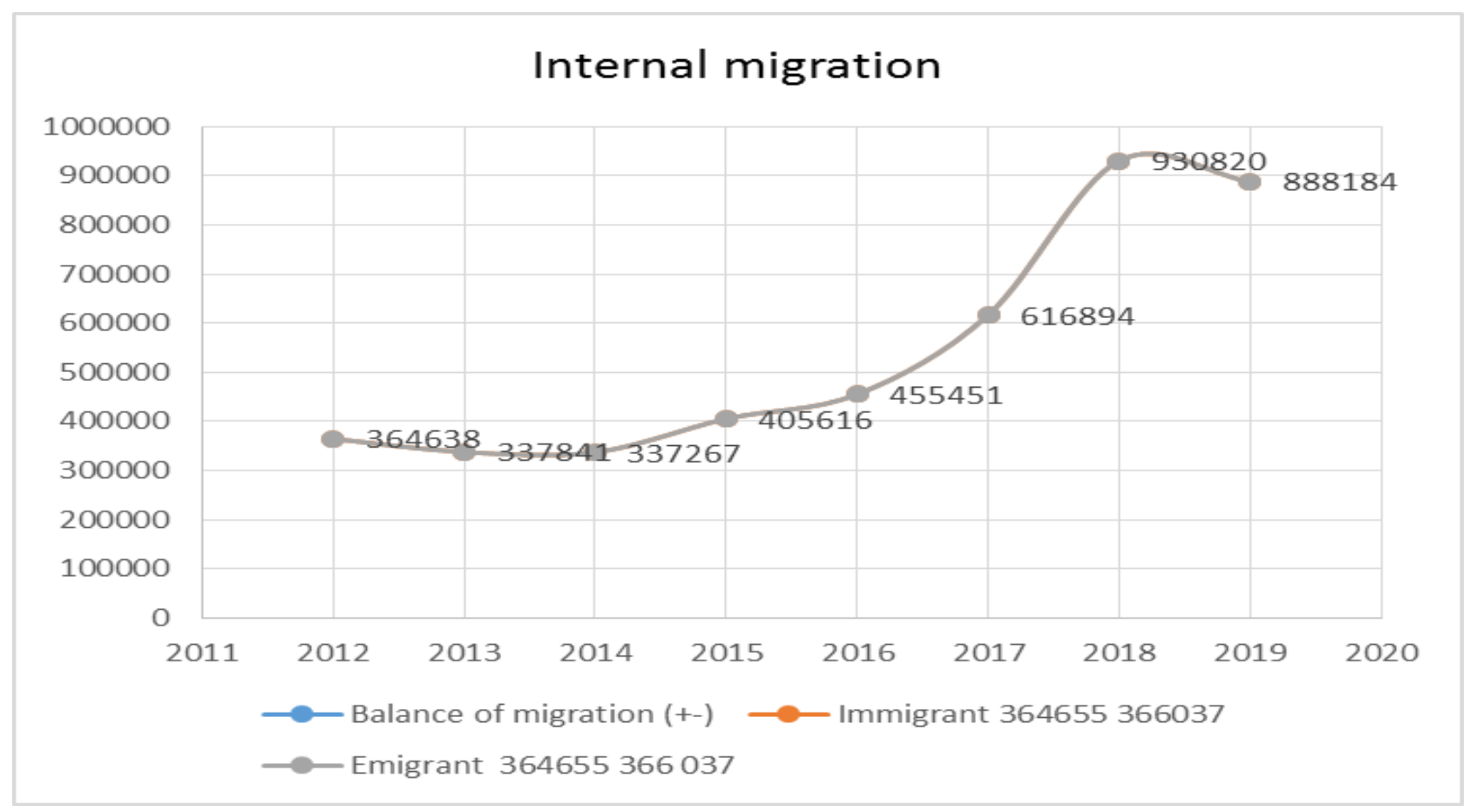

Figure 5. Internal migration of the Republic of Kazakhstan for 2010-2019, person

The data in table 1, figure 2-4 shows that the demographic situation in the Republic is not stable. The migration difference of the republic remains negative due to internal migration in recent years. In accordance with the data of the Committee on Statistics of the Ministry of National Economy of the Republic of Kazakhstan 16.4 thousand families moved to Kazakhstan in recent years, which amounted to 34 thousand ethnic Kazakhs. Of these, $66.2 \%$ came from Uzbekistan, $26 \%$ from China. The remaining migrants arrived from countries such as Mongolia (2.68 $\%)$, Turkmenistan (1.48 \%), Russia (1.42\%), other countries of far abroad (1.5\%) and other CIS countries $(0.68$ \%) (Research Report 2017). However, according to the results of the questionnaire and survey conducted by members of the research group among ethnic migrants living in the Akmola region, 65.7\% of respondents aggravate the situation with internal migration, moving to cities in search of permanent work and income (Bodaukhan, Djussibaliyeva, 2018).

Now, let's consider the types of trending models with which we will work and calculate the impact of indicators on labor potential. An important task is to study changes in the analyzed indicators over time. These changes can be studied if you have data on a certain range of indicators for a number of points in time or for a number of time intervals following each other.

\section{Methodology}

A number of statistical indicators located in a chronological sequence is a time (dynamic) series.

Models based on data characterizing one object for a series of consecutive moments (periods) are called time series models.

One of the problems arising in the analysis of the series of dynamics is the establishment of patterns of change in the levels of the studied indicator over time, i.e. development trends. Thus, the trend is a function of time that determines the main tendency of time indicator development. 
In the analytical alignment of a series of dynamics, a regularly changing level of the studied indicator is estimated as a function of time $\hat{y}_{t}=f(t)$, where $\hat{y}_{t}$ - the levels of the dynamic series calculated by the corresponding analytical equation at $t$ time. Table 3 shows the various types of trend models that are most often used for analytical alignment.

Table 3. Types of the trend models

\begin{tabular}{|l|l|l|}
\hline Item № & \multicolumn{1}{|c|}{ Function name } & \multicolumn{1}{c|}{ Function description } \\
\hline 1 & Lineal & $\hat{y}_{t}=a+b t$ \\
\hline 2 & Second-order parabolic curve & $\hat{y}_{t}=a+b_{1} t+b_{2} t^{2}$ \\
\hline 3 & Cubic parabola & $\hat{y}_{t}=a+b_{1} t+b_{2} t^{2}+b_{3} t^{3}$ \\
\hline 4 & Hyperbolic & $\hat{y}_{t}=a+b \frac{1}{t}$ \\
\hline 5 & & $\hat{y}_{t}=a b^{t}$ \\
\hline 6 & Indicial & $\hat{y}_{t}=a t^{b}$ \\
\hline
\end{tabular}

Thus, a trend model is built - an economic-mathematical dynamic model in which the development of a simulated economic system is reflected through the trend of its main indicators.

The choice of curve shape largely determines the results of trend extrapolation. The basis for choosing the type of curve can be a meaningful analysis of the essence of this phenomenon development. You can also rely on the results of previous studies in this field.

In our research, we will use a linear function, which has the form $\hat{y}_{t}=a+b t$

A linear dependence is selected in those cases when in the initial time series there are more or less constant absolute chain increments that do not show a tendency to either increase or decrease. In this case, a linear trend is built - a straight line equation expressing the trend of the time series.

To estimate the parameters of the time series of model $a$ and $b$, the least squares method (LSM) is used, according to which the model parameters are calculated by the following formulas:

$$
b=\frac{\overline{y t}-\bar{y} \cdot \bar{t}}{\overline{t^{2}}-\bar{t}}, \quad a=\bar{y}-b \bar{t} .
$$

The parameter $b$ is a regression coefficient that determines the direction of development. If $\mathrm{b}>0$, then the dynamics levels increase uniformly, and when $\mathrm{b}<0$, they uniformly decrease. The coefficient $b$ characterizes the average absolute increase. Coefficient $a$ shows the initial level of the time series.

Having built the regression equation, it is necessary to evaluate its adequacy. This is done using the Fisher test $(F)$. The actual level $\left(F_{\text {act. }}\right)$ is compared with the theoretical (tabular) value:

$$
F a c t=\frac{\sigma_{a c t .}^{2}(n-k)}{\sigma 2 \operatorname{rem} .(k-1)},
$$

where $k$ - number of function parameters that describes the trend; $n$ is a number of series levels 


$$
\begin{gathered}
\sigma_{\text {rem. }}^{2}=\frac{\sum\left(y_{t}-\hat{y}_{t}\right)^{2}}{n}, \\
\sigma_{\text {act }}^{2}=\frac{\sum\left(\hat{y}_{t}-\bar{y}_{t}\right)^{2}}{n} .
\end{gathered}
$$

$F_{a c t .}$ Is compared with $F_{t a b}$ for $v_{l}=k-1$ and $v_{2}=n-k$ degrees of freedom and significance level $\alpha$ (usually $\alpha=0,05$ ). If $F_{a c t .}>F_{t a b}$, then the regression equation is significant, i.e. the constructed model is adequate to the actual time trend.

In order to know how well a linear model approximates our data, the coefficient of determination shall be calculated $\left(R^{2}\right)$. The coefficient of determination characterizes the share of variance, explained by regression, in the total variance of the effective feature $y\left(0 \leq R^{2} \leq 1\right)$.

Forecasting in the economy is the transfer of the laws that operated in the past to the future, i.e. the forecast is based on extrapolation. The possibility of extrapolation is provided by two circumstances:

1) the general conditions that determine the development trend in the past do not undergo significant changes in the future;

2) the trend in the development of the phenomenon is characterized by one or another analytical equation.

When making forecasts, they do not operate with a point, but with an interval estimation, determining the so-called confidence intervals of forecasts. The value of the confidence interval is determined in general terms as follows:

$$
\hat{y}_{t} \pm t_{\alpha} \frac{S_{\hat{y}}}{\sqrt{n}}
$$

where $S_{\hat{y}}$ - average deviation from the trend; - tabular value of t-student test at a significance level $\alpha$.

The value $S_{\hat{y}}$ is determined by the formula:

$$
S_{\hat{y}}=\sqrt{\frac{\sum_{t=1}^{n}\left(y_{t}-\hat{y}_{t}\right)^{2}}{n-m}},
$$

where $m$-a number of function parameters that describes the trend; $n$ is a number of levels in the series.

\section{Application functionality. Results and Discussion}

Let's calculate the parameters of linear trend models, check the adequacy of the constructed models, calculate the coefficients of determination and construct confidence intervals for the forecasts for 2020-2021 for the following indicators:

- the population at the end of the period of the Republic of Kazakhstan;

- urban population of the Republic of Kazakhstan;

- rural population of the Republic of Kazakhstan;

- Natural increase (decrease) in the population of the Republic of Kazakhstan;

- External migration;

- Internal migration.

Combined results are provided in table 4, figures 5, 6, 7, 8 . 
Table 4. The results of analysis of the main demographic, migration indicators

\begin{tabular}{|l|c|c|c|c|}
\hline \multicolumn{1}{|c|}{ Indicator } & Trend model & $\begin{array}{c}\text { Coefficient of } \\
\text { determination }\left(R^{2}\right)\end{array}$ & $\begin{array}{c}\text { Verification of Fishers } \\
\text { F-criteria }\end{array}$ & $\begin{array}{c}\text { Forecast values for } \\
2020-2021\end{array}$ \\
\hline $\begin{array}{l}\text { Population of the RK } \\
\text { at the end of the } \\
\text { period, thousand } \\
\text { people }\end{array}$ & $\hat{y}_{t}=18395,6+42,16 t$ & $R^{2}=1$ & $F_{\text {act. }}>F_{\text {tab. }}$. & $\hat{y}_{8}=18589,3$ \\
\hline $\begin{array}{l}\text { Urban population of } \\
\text { the RK }\end{array}$ & $\hat{y}_{t}=10509798+29,05 t$ & $R^{2}=0,97$ & $F_{\text {act. }}>F_{\text {tab. }}$. & $\hat{y}_{9}=18877,43$ \\
\hline $\begin{array}{l}\text { Rural population of the } \\
\text { RK increase }\end{array}$ & $\hat{y}_{t}=7647539+30,27 t$ & $R^{2}=0,98$ & $F_{\text {act. }}>F_{\text {tab }}$ & $\hat{y}_{9}=1140,41$ \\
\hline $\begin{array}{l}\text { Natural } \\
\text { (decrease) in the } \\
\text { population of the RK }\end{array}$ & $\hat{y}_{t}=9,09-0,37 t$ & $R^{2}=0,97$ & $F_{\text {act. }}>F_{\text {tab. }}$. & $\hat{y}_{8}=1068,10$ \\
\hline External migration & $\hat{y}_{t}=399,41+8,49 t$ & $R^{2}=0,78$ & $F_{\text {act. }}>F_{\text {tab }}$ & $\hat{y}_{9}=1098,37$ \\
\hline
\end{tabular}

Thus, we can draw the following conclusions:

- the coefficients of determination of the constructed models are quite close to unity, which speaks in favor of the models;

- constructed trend models are adequate;

And so: Forecast values for 2020-2021:

Population at the end of the period of the Republic of Kazakhstan: $\hat{y}_{8}=18589,3, \hat{y}_{9}=18877,43$

Urban population of the Republic of Kazakhstan: $\hat{y}_{8}=1140,41, \hat{y}_{9}=1169,46$

Rural population of the Republic of Kazakhstan: $\hat{y}_{8}=1068,10, \hat{y}_{9}=1098,37$

Natural growth (decrease)population of the Republic of Kazakhstan: $\hat{y}_{8}=6,14, \hat{y}_{9}=5,78$

External migration: $\hat{y}_{8}=467,36, \hat{y}_{9}=475,85$

Internal migration: $\hat{y}_{8}=949, \hat{y}_{9}=739$

With a probability of $95 \%$, it can be expected that in 2020 - 2021 the considered indicators will not take values smaller than the lower bounds of the confidence forecast intervals and not greater than their upper bounds. 
ISSN 2345-0282 (online) http://jssidoi.org/jesi/ 2020 Volume 8 Number 1 (September) http://doi.org/10.9770/jesi.2020.8.1(45)

\section{Conclusions}

The migration turnover in the country depends on the openness of state borders, the geopolitical situation in the republic, the stability of interethnic relations, as well as the legal framework for migration, and the level of state regulation. North Kazakhstan region occupies the 5 th place in terms of population density of 5.66 people / $\mathrm{km} 2$, and the regions with low population density include Mangistau and Aktobe regions - population density per 1 sq. $\mathrm{km}$. is 2.3 people. In cities, the leading place in demography and fertility in 2019 is held by Almaty and Nur Sultan. The process of shredding the rural settlement network, which lasted over 10 years (more than half are small, with a population of less than 500 people, where $9.8 \%$ of the rural population lived), complicated the social arrangement of rural areas, which led to a migration outflow of the able-bodied population, especially youth, from village to city and the inevitability of urbanization. In rural areas, socio-economic imbalances between the level and quality of life still persist. Currently, $42 \%$ of the country's population lives in rural areas. The main results of the labor market of urban and rural population are presented in the final table 5, figure 5.

Table 5. Key indicators for comparing the labor market of urban and rural population

\begin{tabular}{|c|c|c|c|c|c|c|c|c|c|c|}
\hline & \multicolumn{2}{|c|}{2014} & \multicolumn{2}{|c|}{2015} & \multicolumn{2}{|c|}{2016} & \multicolumn{2}{|c|}{2017} & \multicolumn{2}{|c|}{2018} \\
\hline & city & village & city & village & city & village & city & village & city & village \\
\hline Man power, thousand people & 973,3 & 988,6 & 5118,5 & 3769,1 & 152,3 & 846,6 & 5187,3 & 3840,1 & 277,2 & 861,4 \\
\hline $\begin{array}{l}\text { Employed population, thousand } \\
\text { people }\end{array}$ & $\begin{array}{r}4 \\
715,3 \\
\end{array}$ & $\begin{array}{r}3 \\
794,8 \\
\end{array}$ & 4858,5 & 3574,9 & $\begin{array}{r}4 \\
890,7\end{array}$ & $\begin{array}{r}3 \\
662,7 \\
\end{array}$ & 4932,0 & 3653,1 & $\begin{array}{r}5 \\
017,5\end{array}$ & 3677,5 \\
\hline \multicolumn{11}{|l|}{ Employment level, in percent to: } \\
\hline Number of man power & 94,8 & 95,1 & 94,9 & 94,8 & 94,9 & 95,2 & 95,1 & 95,1 & 95,1 & 95,2 \\
\hline Employees, thousand people & $\begin{array}{r}3 \\
884,7 \\
\end{array}$ & $\begin{array}{r}2 \\
225,0 \\
\end{array}$ & 4069,0 & 2225,9 & $\begin{array}{r}4 \\
102,0 \\
\end{array}$ & $\begin{array}{r}2 \\
240,9 \\
\end{array}$ & 4160,2 & 2325,7 & 4226,7 & 2385,7 \\
\hline $\begin{array}{l}\text { Share in employed amount, in } \\
\text { percent }\end{array}$ & 82,4 & 58,6 & 83,8 & 62,3 & 83,9 & 61,2 & 84,4 & 63,7 & 84,2 & 64,9 \\
\hline Self-employed, thousand people & 830,6 & $\begin{array}{r}1 \\
569,8\end{array}$ & 789,5 & 1349,0 & 788,7 & $\begin{array}{r}1 \\
421,8 \\
\end{array}$ & 771,8 & 1327,4 & 790,8 & 1291,8 \\
\hline $\begin{array}{l}\text { Level of unemployed people, in } \\
\text { percent }\end{array}$ & 5,2 & 4,9 & 5,1 & 5,2 & 5,1 & 4,8 & 4,9 & 4,9 & 4,9 & 4,8 \\
\hline $\begin{array}{l}\text { Of youth (at the age of } 15-28 \text { years } \\
\text { old) unemployment, in percent }\end{array}$ & 5,0 & 3,4 & 4,8 & 3,8 & 4,6 & 3,5 & 4,4 & 3,3 & 4,4 & 3,1 \\
\hline $\begin{array}{l}\text { Level of long-term unemployment, } \\
\text { in percent }\end{array}$ & 2,1 & 2,6 & 2,2 & 2,8 & 2,2 & 2,3 & 1,9 & 2,5 & 1,9 & 2,7 \\
\hline $\begin{array}{l}\text { People not related to man power, } \\
\text { thousand people }\end{array}$ & $\begin{array}{r}2 \\
193,1\end{array}$ & $\begin{array}{r}1 \\
522,8 \\
\end{array}$ & 2281,3 & 1586,1 & $\begin{array}{r}2 \\
339,3 \\
\end{array}$ & $\begin{array}{r}1 \\
515,7 \\
\end{array}$ & 2410,0 & 1517,2 & 2431,2 & 1476,1 \\
\hline $\begin{array}{l}\text { Share of people not related to man } \\
\text { power, in percent }\end{array}$ & 30,6 & 27,6 & 30,8 & 29,6 & 31,2 & 28,3 & 31,7 & 28,3 & 31,5 & 27,7 \\
\hline
\end{tabular}

Considering the peculiarities of development of the agri-food sector and the growth of income from agricultural activities, the existing surplus of rural population is one of the reasons for restraining the growth of the standard of population living, which complicates the planning of sustainable development of the country (Akimbekova, 2019). 


\section{ENTREPRENEURSHIP AND SUSTAINABILITY ISSUES}

ISSN 2345-0282 (online) http://jssidoi.org/jesi/

2020 Volume 8 Number 1 (September)

http://doi.org/10.9770/jesi.2020.8.1(45)

In the long run, urban employment has a steady upward trend. However, in rural areas there has been a steady decline in employment. In addition, significant differences between urban and rural areas persist in the structure of employed population. So, $84 \%$ of the urban population are employees, the remaining $16 \%$ are self-employed. In rural areas, the share of employees is only $61 \%$, and the share of self-employed workers is $39 \%$ (Nurzhanova et al., 2020).

As a result of the analysis of migration, demographic processes and their impact on the development of the Republic of Kazakhstan economy at the present stage, the following conclusions can be drawn.

The positive result of labor potential development is influenced by many different, as well as interdependent factors such as urban and rural population, natural increase (decrease) in the population, external migration and internal migration.

Knowledge of the mechanisms of interaction of these factors, as well as its impact on labor potential and the entire economy as a whole, is very important for developing a strategy for the demographic and migration situation.

A factor analysis of the population migration causes, the demographic position of the republic allows us to conclude that the development of external migration is the main cause of historical and ethnic factors, and the development of internal migration of socio-economic factors.

An analysis of internal migration flows shows that in recent years there has been a tendency for migration to cities for rural people. Having studied the topic, we can draw the following conclusions:

- the trend model shows that the coefficients of determination of indicators of total population, urban and rural population, internal and external migration with natural population growth are quite close to unity, which speaks in favor of models;

- constructed trend models are error-free, authentic; research limitations related to accuracy of secondary data are typical to such researchers.

\section{References}

Akimbekova, Ch.U. 2019. Problems and prospects of the Kazakhstan village in terms of rural development. Agrary newspaper, June 25, № $12(74)$

Abenov, Y.M., Kirdasinova, K.A., Tulaganov, A.B., Zhumataeva, B.A., Mutalyieva, L.M., Issayeva, B.K. (2019).

Entrepreneurship education: Teaching and learning modern mechanisms of entrepreneurship development based on public- private partnership. Journal of Entrepreneurship Education, 22(5).

Baltgailis, J. 2019. The issues of increasing the effectiveness of teaching comparative economics, Insights into Regional Development 1(3): 190-199. https://doi.org/10.9770/ird.2019.1.3(1)

Bezu, S., Holden, S. 2014. Are Rural Youth in Ethiopia Abandoning Agriculture? World Development 64 (Supplement C), $259-72$.

Bodaukhan, K. 2017. The role of ethnic migration in the development of the agricultural sector of Kazakhstan. Materials of the Republic scientific-theoretical University's 60th Anniversary Conference. "Seifullin readings - 13". Astana: S.Seifullin Kazakh Agrotechnical University, April 21, 92-96.

Bodaukhan, K., Djussibaliyeva A.K. 2018. The impact of migration processes on employment in agriculture of the Republic of Kazakhstan. Problems of the Agricultural Market. 1, Almaty, January - March, 23-29.

Brodunov A. N., Ushakov V. Ya. Justification of financial decisions in conditions of uncertainty // Bulletin of the Witte Moscow University. Series 1: Economics and management. - 2015. - № 1 (12). - Pp. 30-36. 


\section{ENTREPRENEURSHIP AND SUSTAINABILITY ISSUES}

ISSN 2345-0282 (online) http://jssidoi.org/jesi/ 2020 Volume 8 Number 1 (September) http://doi.org/10.9770/jesi.2020.8.1(45)

Bunevich K. G., Petrov D. M. Development of dual-use technologies based on the cluster approach // Bulletin of the Witte Moscow University. Series 1: Economics and management. - 2013. - № 1 (3). - Pp. 75-79.

Chehabeddine, M., Tvaronavičienè, M. (2020). Securing regional development. Insights into Regional Development, 2(1), 430-442. http://doi.org/10.9770/IRD.2020.2.1(3)

Dal, V.I. 2018. Explanatory Dictionary of the Living Great Russian Language, Nur-Sultan p.344. "Demographic potential of the Republic of Kazakhstan for 2010-2019“, p. 60

De Brauw, A. 2014. Migration, Youth, and Agricultural Productivity in Ethiopia. Paper presented at Allied Social Science Association (ASSA) Annual Meeting, Boston, Massachusetts.

De Brauw, A., V. Mueller, and T. Woldehanna. 2013. Motives to Remit: Evidence from Tracked Internal Migrants in Ethiopia. World Development 50 (Supplement C): 13-23.

Fedorov V.B. 2004. Agricultural personnel: experience and problems. Lenizdat, 230 p.

Harris, J., Todaro, M. 1970. Migration, Unemployment and Development: A Two-Sector Analysis. American Economics, 60(1), 126-42.

Iontsev, V.A., Prokhorova, Yu.A. 2014. International population migration in the context of demographic theory. The magazine "Living Standards of the Population of Russian Regions", 3(193), 83.

Kostakov, V., Popov, A.1982. Intensification of labor potential use. Social Work \& Society, 7, 61 - 63.

Ministry of National Economy of the Republic of Kazakhstan https://www.developmentaid.org/\#!/donors/view/150429/ministry-ofnational-economy-of-kazakhstan; www.enbek.gov.kz

Mukhammedov A. U. Economic problems of state regulation of population migration. Abstract of the dissertation for the degree of doctor of Economics, Republic of Kazakhstan, Almaty, 2007. 34, 6 p.

Nurzhanova, G. I., Niyazbekova Sh. U., Nurpeisova, A. A, Imangozhina, Z A., Satenova. D. E. 2020. Youth labor Market Analysis and Assessment of the Republic of Kazakhstan. International Scientific Conference "Far East Con" (ISCFEC 2020), 17 March, 360 -366, https://doi.org/10.2991/aebmr.k.200312.053

Semenyuk Olga, Sabina Kuc, Sara Sadykova, Kaldybay Arynov, Ella Beloussova, Shakizada Niyazbekova, Buldyryk Suleimenova. New educational programmes as a factor in forming students' innovative competencies. Vol.17, No.3. 2019. World Transactions on Engineering and Technology Education. EID: 2-s2.0-85080897539

http://www.wiete.com.au/journals/WTE\&TE/Pages/Vol.17,\%20No.3\%20(2019)/26-Semenyuk-O(1).pdf

Semenyuk O., Abdrashitova T., Beloussova E., Nechay N., Listkov V., Kurbatova V., Niyazbekova S. 2018. The influence of ecology and economic factors on eco-architecture and the design of energy efficient buildings. World Transactions on Engineering and Technology Education, 16(2), 186-192. EID: 2-s2.0-85047534215

Report on the research work on the topic "Study of relationship of the ethnic migration flow with the development of agriculture and development of recommendations for attracting and retaining ethnic migrants in agriculture (based on materials from the Akmola region)" (final). - Astana: S. Seifullin KATU, 2017. 65 p.

Tvaronavičienè, M., \& Ślusarczyk, B. (2019). Energy transformation towards sustainability. Energy Transformation Towards Sustainability (pp. 1-333) https://doi.org/10.1016/C2018-0-02510-4 Retrieved from www.scopus.com

Tvaronavičienė, M., Razminienė K. (2017). Towards competitive regional development through clusters: approaches to their performance evaluation. Journal of Competitiveness, 9(4), 133 - 147. https://doi.org/10.7441/joc.2017.04.09

Vigliarolo, F. 2020. Economic phenomenology: fundamentals, principles and definition. Insights into Regional Development, 2(1), 418429. http://doi.org/10.9770/IRD.2020.2.1(2) 


\section{ENTREPRENEURSHIP AND SUSTAINABILITY ISSUES}

ISSN 2345-0282 (online) http://jssidoi.org/jesi/ 2020 Volume 8 Number 1 (September) http://doi.org/10.9770/jesi.2020.8.1(45)

Gulmira NURZHANOVA Doctoral student of Economics and management Department, JSC Financial Academy, NurSultan, Kazakhstan. Research interests: economy, labor potential, labor resources.

ORCID ID: https://orcid.org/0000-0002-1456-2157

Galym MUSSIROV Ph.D., Senior Lecturer, Baishev University, Aktobe, Kazakhstan. Research interests: economy, finance, management, labor potential, labor resources

ORCID ID: https://orcid.org/0000-0003-2853-6504

Shakizada NIYAZBEKOVA Candidate of Economic Sciences PhD, Moscow Witte University, Moscow, Russian. Research interests: economic, finance, management, labor potential, labor resources

ORCID ID: https://orcid.org/0000-0002-3433-9841

Akilbek ILYAS Doctor of Economic Sciences, professor of Financial Academy JSC, Department of Finance and customs, Nur-Sultan, Kazakhstan. Research interests: finance, economics, ecology, management, labor potential, labor resources

ORCID ID: https://orcid.org/0000-0002-6655-6277

Yuliya TYURINA Doctor of economic sciences, associate professor, Professor of the Financial University under the Government of the Russian Federation, Moscow, Russian Federation

Research interests: economic, finance, management, labor potential, labor resources

ORCID ID: https://orcid.org/0000-0002-5279-4901

Leila MAISIGOVA Candidate of Economic Sciences, Ingush State University, Magas, Russian Federation Research interests: economic, finance, management, labor potential, labor resources

ORCID ID: https://orcid.org/0000-0003-2148-4924

Marija TROYANSKAYA Doctor of Economic Sciences, Associate Professor, Orenburg state university Research interests: economic, finance, management, labor potential, labor resources

ORCID ID: https://orcid.org/0000-0003-4545-3786

Kymbat KUNANBAYEVA is senior teacher, Financial University under the Government of the Russian Federation, Moscow, Russian Federation.

Research interests: management of city-forming organizations, economic of organizations, single-industry town, social controlling.

ORCID ID: https://orcid.org/0000-0002-5846-855X

Make your research more visible, join the Twitter account of ENTREPRENEURSHIP AND SUSTAINABILITY ISSUES:

@Entrepr69728810

Copyright (C) 2020 by author(s) and VsI Entrepreneurship and Sustainability Center

This work is licensed under the Creative Commons Attribution International License (CC BY).

http://creativecommons.org/licenses/by/4.0/

(c) (7) Open Access 